\title{
THE SECOND LAW
}

\author{
Dennis Andrew S. Aguinaldo \\ University of the Philippines Los Baños \\ dsaguinaldo@up.edu.ph
}

\begin{abstract}
About the Author
Dennis Andrew S. Aguinaldo teaches prose at the Department of Humanities of the University of the Philippines Los Baños. He received creative writing fellowships from the University of the Philippines, University of Santo Tomas, De La Salle-IYAS, and the Ateneo's AILAP. His works have appeared in magazines like the Sunday Times and in anthologies such as the PEN collected volumes. He regularly attends workshops for two student organizations: PANTAS and the UPLB Writers' Club.
\end{abstract}


For thou shalt worship no other god: for the Lord, whose name is Jealous, is a jealous God.

- Exodus 34: 14

1972.

Mari Tsuji played the game one week after Ian Kasimiro left New York to look for his wife, Gina. He said she could do whatever she wanted with his books, notes, clothes, and the apartment keys which were good for three months before the landlady would come to collect them.

The game was sortes Vergilianae, one of the simpler things that Ian Kasimiro taught her. "All seminarians enjoyed the trick," he said, "jumping around as they did from one Bible page to another. But how many of them knew its provenance? That this method was used by princes and governors upon the Aeneid long before the King James came along? It's easy. Take hold a question in your mind, sweet Mari. Get a sizeable book of some worth-but size itself is more essential than content, remember-and open it on any random page. From that page plucked by chance, find your answer."

It was the sort of thing he encouraged when he was with her.

There were three notebooks on Ian Kasimiro's portable drawing board. They were thick enough, she thought. Maybe 1,500 pages all in all. She never touched them before because there were many other things to do whenever he was around, and she was never much for reading - was that why he left? - but now she had a question in her heart. How had Ian Kasimiro chosen his wife?

She opened all three of his notebooks, spread them on the dining table, and began looking for her answer.

(1)

....aside one afternoon, and brought me to their patio. I remember the acacia flowers in the wind and my fear that he would forego the recommendation completely and talk to me about his daughter instead. But the Pastor said: I am not sure I should be recommending you. I am not sure about your faith. At least not yet. Maybe you should finish your dissertation here, you're still very much welcome in my house.

I said: "I am industrious, a forehead keen with promise, as you yourself once said. I only ask that you put it down on paper, and below it, affix that signature of yours which is for me, of greater significance than those of my esteemed professors." 
But Pastor Sheil talked about my "pleasant, altogether articulate" participation in the cell group readings, and how, although he understood that the scholarship gave me a good shot out of the rut, he still found it alarming when I said some things, once for example, when he asked "why don't you concentrate on keeping your family together?" and I answered my concentration would only shatter them, and another time when he asked me to choose which was greatest among the Gospels and I answered that if we piled the books of the Bible one atop the other in terms of worth, I'd put the Ecclesiastes above all four of the Gospels.

Do you remember the things you said? He asked.

I said: "I remembered saying that between the Gospels and the Ecclesiastes I'd insert a note or two of the Songs. But if the quality of my reverence is in question, I should remind you about my father. If you would care to listen, I said, and he said he would listen although I saw that his face was tight against whatever I was about to say.

"Have you forgotten where I came from?"

He said: No, you took me there once. How could I forget? I remember watching a drunkard wield hammer and chisel, absently perfecting a face for his poon.

I said: “When dealing with faces, mere symmetry doesn't amount to perfection. Had you asked him for perfection, he'd have taken you to my father."

Man among men, gaunt as a post that supports no house, a post standing in the middle of nowhere fields, but I have already told the Pastor much about my father, back then, on our way to Paete, even showed his pictures when we arrived.

I kept Tatay's workshop closed.

Tatay came from two distinct lines of master craftsmen, his hands unanimously considered by that town of artisans-egotists all-as the twin flowers of Paete. He was commissioned more often than anybody else. While the other masters envied his ambidexterity, the younger men desired his ability to juggle blocks of wood, even sharp tools and a ball peen hammer, up to four materials of various weights and shapes, all of them up in the air at any given time.

Aware of the envy of menfolk and the ruin it could cause his business, my father courted their friendship with alcohol and his petty carnival antics. He nurtured such friendships on a weekly basis. This practice would eventually corrode his liver, gain him months at the local hospital, and leave us with very little money. 
When I was a boy, I once came along on a hunt for the finest century wood. It took him all of two days to acquire the logs with the grain he desired. Then I watched him working on an exceptionally delicate face of the Mater Dolorosa. The people marveled at the result. The Dolorosa would spend three weeks in our parish before its transport to Mexico's San Cayetano Church-on August 26, I still remember it-the date was announced at the pulpit. For three weeks, the parishioners, along with numerous visitors from neighboring towns, prayed exclusively to that Mater Dolorosa.

On the afternoon of August 25, Tatay stopped to look at the people and said: They should be praying to me.

I was eight then, and he wasn't saying those words to me.

"You remember what he said in the presence of the Mater Dolorosa? I'm still struck by it now, please understand," I said to Pastor Sheil.

"Listen, when I was around eleven, I tried to confirm something else that my father said: No artisan ever knelt before a poon. I watched his friends during the holy mass and the prusisyon. They all watched while their families knelt or kissed the robes. Tatay was correct for he was their chief. Why would the Lord God make such a race of men possible?

"You think me irreverent dear Pastor. You question my faith. I question it myself, ceaselessly, with a relentlessness that weighs upon the eyes and the chest, Pastor. Kindly remember how these questions led me to your magnanimous church. If you won't recommend me on the basis of my faith, then sign your name on the strength, sincerity, and validity of my questions."

Night had fallen by the time we entered the house. His daughter had dinner waiting for us. The Pastor said grace with a reading of the parable of the talents. We talked about my plans for the children. They must go to Davao, I said, where my admirable father-inlaw could take care of them. Two checks will be released every month, one for Davao and another for this ministry that supported me and must be supported in return. Also, something for Marikina and Paete when there's extra.

I'll get me a job there, with or without the Thomson's consent. Assist in a library or wait on tables. Wash cars.

His daughter was silent, that is to say, not her usual bubbly self. I suspected she was pale, but I could not judge with only my passing glances and peripheral vision. I then wondered if her father had any inkling of Bridget's true capacity for hysterics. 
Within that week, I gained Pastor Sheil's recommendation, the least significant of the three signatures necessary for my application to the Thomson Memorial Scholarship, my pass to the City University of New York.

(2)

Boltzmann.

Ludwig Boltzmann.

Ludwig Boltzmann.

Ludwig Boltzmann.

You.

You were in fact the reason why I lost the national finals of the Math and Science Quiz Bee, High School Division. Only three contestants remained in the last leg of the competition. It was a tie between the boy from Tarlac and the girl from Leyte. I was ahead by 15 points, but the proctor lobbed a 50-point question at us.

"I'm looking for a scientist, one who was the first to state the logarithmic connection between probability and entropy. In other words, this scientist posited a statistical definition of entropy. Give me his full name..."

The only names I had back then regarding entropy were Rudolf Clausius and Saddi or was it Sadie Carnot, but I could not peg down the exact nature of their contributions. I could not remember which of them used statistics. Between Carnot and Clausius, Carnot came earlier. So I voted Clausius because the growing place of statistics in the scientific method was a later development. $19^{\text {th }}$ century.

The proctor added a clue. "He committed suicide when he was $62 . "$

Tarlac frowned. Leyte smiled. I was hoping that Clausius was a tormented man, and fatally so. But he wasn't. You were. And so Leyte became champion, bagged the big scholarship. She spelled your name wrong though-Boltzman, single N-but I had never heard of you so I only discovered this later, after hitting the books. By then, it was too late to protest.

Nevertheless, I continued to read everything I could about you: the intellectual debts that Planck and Einstein owed you, the field of physics established in the wake of your work, that birthday between Mardi Gras and Ash Wednesday, that death by hanging, and the unwavering (but back then, a highly unfashionable) faith in the existence of the atom.

I began teasing out the possibilities from your formulae, your tortuous equations. Generation after generation of expert mathematicians had registered their complaints, 
but I was determined to get back at you-a stump of a guy who cost me my free ride through college: tuition, lodgings, all the books I could have wanted, clothing and transportation allowance, and a fat monthly stipend. Gone away. Everything, on a slow boat to Leyte.

Second place earned me a sizeable sum, but Tatay asked for all of it. He said U.P. would eventually give me a decent scholarship anyway. He arranged a graduation party for me, the liquor flowing, a whole roast pig on the central table. It felt like half a wedding.

He was drunk when he said it, but he said it. BS Physics would lead me away from the chisel. He was glad, he said again. Glad.

Inay went to Marikina to visit her sister, my Tia Prising, and made arrangements for me to stay at her place. Tia rented out her spare rooms for extra income, but she was glad to sponsor me for free. Since then, Inay always packed kakanin for her whenever I came to Marikina after my weekends or holidays at Paete.

I once told my parents how there wasn't a quality Poon at Tia Prising's house. Wasn't it a splendid idea for a gift? They ignored me even after I repeated my question.

I shared my room with Rey Waje, a tall guy and a Political Science major. He came from a place called Quisao in Rizal and knew what it meant to come from the province. I won the upper bed of the double-deck with a flip of a coin: tails. Luckily, there was enough sitting space up there. I had built myself a portable drawing board with some leftover narra from Tatay's workshop so that I could work anywhere, on the bed if I wished. Turned out that I did my best work there. My sweet spot.

However, a stretch of three cabinets nailed up the ceiling compromised my space somewhat. These cabinets had been thoroughly vandalized by previous tenants. The only note worth remembering was one written with a red pen, lines from Heraclitus the Gloomy.

Time is a child

playing backgammon.

Royalty of a child.

Of those cabinets, two were available, one for my books and the other for my clothes. The remaining cabinet was locked, the one right above my face whenever I slept. I can't remember how it happened—and I have a fairly capable memory—but I began sounding off my lessons against that locked cabinet (of course I had to hold discussions in my head whenever Rey was around, and I could carry on for hours like that as long as I was looking at the cabinet). I went on to solve my problem sets off it, throw questions at it, and ask it to help me recall the missing strings of formulae or the components of some 
makeshift mnemonic or other. Whenever I encountered any difficulty during exams, all I had to do was close my eyes and visualize the cabinet. This would immediately unclog my mind.

Then Tatay's liver failed. He died on my sophomore year. I found it very difficult to concentrate on anything. Weeks after the funeral, I was still having trouble with my studies.

Even the cabinet was no help. That is, until I began referring to it as you. Soon Professor Boltzmann, you were indispensible. In fact, after graduation I wanted to saw the whole thing off the ceiling and lug you out to the Pastor's place.

Pastor Sheil—the Irish minister who facilitated the Bible readings I attended-had by then offered me a place to stay while I finished my Master's degree. This complemented my new scholarship which would only cover tuition and stipend. He would lend me a much bigger room as long as I kept praying with them, editing their newsletter, committing myself to other errands of like nature.

Good, OK. What ingratitude though if I leave my aunt's room mutilated!

So I said, Boltzmann you brought out the best in me, all these years, but as it turns out, you're a crutch and I absolutely must fly. When you're gone, I'll figure out some other way to study. As it stands, I have one feasible idea to get rid of you.

"At least now," you said, "I don't have to bring destruction upon myself like I did back in the day. So what's on your mind, Ian? Let's hear it."

I'll open the cabinet. I'll fetch the key, open you up, and demystify you once and for all. You'll disappear. I'll go through denial before withdrawal, but in the end I'll cope.

"Let's have your aunt then. She'll set us up for proper goodbyes."

While Tia Prising was helping me pack my things and clean the room, I asked her about the locked cabinet.

My question startled her, but she did manage an answer.

Well, I guess you're old enough, said Tia Prising. Do promise to keep this between the two of us. I could show you the angels and roses I have up there, but I can't recall where I left the key. It's been so long since I used it. Mostly, those things were made from sandalwood although I think your father committed the atrocity of carving the roses from rosewood. And a pile of letters. How do I say this? Your father courted me before 
he married your mother. Don't tell your mother I still have these things, Ian. You're old enough I think, so there's no harm.

"Termite-food, by any other name. We have a saying in Austria," Boltzmann said. "You can ease a man out of the cabinet, but God help you should you pry that cabinet loose from the man."

(3)

...maybe seven years old. But you know, vanity. Anyway, I had been begging my father to allow me go to the perya at the plaza. Tatay thought it would be a waste of money. Inay said that I had been a very obedient boy, that I even fetched water without waiting for orders, so maybe my father should reconsider.

Next morning, my father left coins for me at the breakfast table. It was a long walk away, near the church and not as far as the school. I was to use the money wisely. I could buy a toy if I wished, but I must not gamble. I could watch the rat race or the children tossing coins on the wide yellow checkerboard, but I must place no bet and toss no coin. My mother told me to come home for lunch, or she would spank me with both her brooms.

I asked if I could take either of my little sisters with me. I would be responsible for them. No, they were too young.

I watched the kids at the color game. The game was an old suitcase with a paper tube and a block of wood. The block had a different color painted on each side. It was a die with colors instead of dots.

A kid could bet a centavo or two on any color of choice: white, blue, gray, green, red, and orange. The man placed the money on one of the six colored cans. Triple the money if the kid's color turns up. Sometimes the man would let a kid pull the lever to release the block onto the box. There were a lot of us who just stood there to watch while some of the kids played.

There was almost always a winner, but to dissuade myself from playing, I reasoned that there were consistently more losers in any given round than winners. My attention drifted from the block and went to the colored cans. In my mind, I summed up the money per round, subtracted the winnings of the lucky kid (or kids), and derived the earnings of the man. In the span of fifteen rounds, the man only lost once. This amazed me.

A kid came, obviously buena familia. She placed a coin on each can per round. Her way with the game was wrong, and her strategy assaulted my senses. She thought she 
was winning the whole time, but I knew she was losing with each round. Some other kid followed her lead, a boy. He also thought that he had a winner method. The man didn't react. He'd seen this before. What a mistake! I shouted at the two kids, told them that they must choose just one can. The gray can, the gray can! Gray came out around a couple more times than any of the others, I said, don't you see? The boy was about to hit me, but the girl stopped him by giving him a coin. She gave me two.

The man left, and so did everybody. I was happy to have enough money to buy cotton candy for both my sisters. I was halfway home with a cotton candy up each hand when it began to drizzle. I ran so that I would not get sick.

Inay laughed when she saw me holding up two meaningless sticks. Tatay scolded her for making unseemly noise, then he pointed me to the poso so which meant I should take a bath. I was to take a bath before a beating. The yantok was as thick as mother's wrist. It would take me years (now, this moment) to realize that he had far heavier sticks (and tools!) at his disposal: choosing the yantok meant fifteen minutes of mercy.

A sandalwood angel. The Mater Dolorosa. Cotton candy. Mari Tsuji closed the notebooks and wondered. Which (if neither all nor none) of these three pieces informed Ian Kasimiro's choice of a wife?

She also wondered why he called the sortes Vergilianae a game when there seemed to her absolutely no evidence, no promise of either winning or losing.

Besides the sortes, he taught her some other games-Greco-Roman and Filipino mostly-and of course, nightly heapings of French. All that was behind her now. She was remembering the paradox of the Greek, how once when she came in from work and was about to embrace him, Ian Kasimiro held up his hand. His eyes stopped her cold. "Before this," he asked, "are you prepared to admit that this distance between us could be cut in half?"

She nodded. That's common sense.

“That these two resulting halves could each be cut in two, so that we have four?"

"Yes. Should I just get dressed then? Are we off to the café?"

"That we can cut each of these four pieces into halves? Likewise, the resulting eight pieces? $16,32,64,128$ and so on? Will you admit the undisputable infinity of halves between us?" 
"If it comes to that, yes. We'll need our coats."

"How can we sit so still, Mari? How does it happen, how can we affirm this expanse-it's growing before my eyes! - and yet you and I, how can we labor under the belief that you could actually touch me?"

She slapped him. Then she slapped him two more times. Her right hand, his left cheek.

Six weeks after that, alone in his apartment, and entirely within the theater of her mind, Mari Tsuji continued slapping his left cheek. This does not have to end, she thought. With each slap, she imagined cutting the space between Ian Kasimiro and his wife.

LUDWIG BOLTZMANN: Do you believe I made this magnificent aircraft possible?

IAN KASIMIRO: The engines would not be half as efficient without a decent study of entropy. An established engineer would hand you your yes more effectively, citing the importance of your statistical mechanics on both the build of the craft, the necessary dispersal of fluids, as well as the analysis of the sky and its plentiful molecules. But in my fashion I shall give you the same honor-

LB: If such an engineer were available, Ian, I would thank you if-

IK: It was you who intuited how utterly unlikely it was that a steadily silent universe would spew out the furious stars, the sun-electrified seas, and the teeming, boisterous minds that would conjure this technology. Yet it did. Correctly, you refrained from calling this set of instances either miracle or anomaly. It was merely this: the universe had a couple of billion dice and infinite time to throw them. Sooner or later-infinitely sooner or infinitely later-all those dice would turn up sixes. It's extremely rare, but it's there. That possibility. Hence this plane. Hence you, hence me, the dictator, my family.

LB: If you have no greater elegance than that, take me to the engineer. Maybe he would tell his wife about me. 
IK: Nor would I bequeath you to my children. You end with me, Boltzmann. Don't you believe that everything that is likely will happen? Has happened?

LB: Is happening? Had been happening? Shall go on occurring as occurrences are wont to do given infinite time? Shall phenom all over the place, or shall have already phenommed, as if the universe had nothing better to do than play phenomena over and over until the vinyl gets degraded to a state of complete material incoherence? Must I remind you: infinity means nothing much going, and you'd do well not to dwell on these things while you're miles up among unpredictable clouds. Already your guts are churning. You'd be a terrible burden to these amiable attendants.

IK: There's precious little sense in telling Gina about you. She's already aware of her lapse in judgment when she decided to marry me. It would do her no good to perceive the actual dimensions of that lapse.

LB: You call me fat. You have been accusing me of obesity since day one. Yet you fit me snug into a cabinet. And now, this form.

IK: Could not be helped.

LB: You have enough pictures of me. I can tell you where to get more if you wish.

IK: As you said, I possess enough of your images. I have as little control over your recent or future shape as I did when you were alive.

LB: You even visited my grave! Why did you shove me into this form? Have you so mean a stretch of imagination?

IK: Which fact do you detest more, I wonder, your composition of iron nails and batikuling wood or your possession of the likeness of my father?

LB: That you topped me with the Rastafarian hair of your small town Jesus.

IK: That's Tatay's hair, show some respect. Jesus sported thorns and rays. And I maintain that I had no control over the outcome of your shape. Would you rather have thorns?

LB: You don't wish to introduce me to your wife because you fear that communicating me would double me. And further communication, especially to your children- 
IK: On the other hand, you want me to talk to my wife about you because our discourse could possibly alter your current shape.

LB: Oh, that sweet discourse of hers could annihilate me. Why can't this thing fly any faster?

IK: Gina is lovely, but that's beside the point.

LB: For you, she is entirely beside the point. Curie and Max, these kids remain equally beside the point. Even dear Ms Tsuji is beside the point. You would say that the dictator is beside the point, likewise the country that is approaching you as quickly as you are approaching it. Your wife wouldn't say things like that, Ian Kasimiro. So tell me, what is the point?

IK: I don't know, Professor Boltzmann, but I'm dead certain that whatever it is, it's somewhere here, somewhere between us.

\section{Dear Mr Asumen:}

Thank you for sending me news of my family, the progress of Max and little Curie, but particularly the terrible report about Gina. I'm sorry I wanted to reply sooner, but I thought it wrong to write without describing any sort of plan to retrieve my wife, your dear daughter. Let me assure you that I wasted no time. Calls were made to some people.

I have an appointment with Major Waje, an old friend. Your daughter was also acquainted with him, but I'm not sure if she ever told you about him. In fact, it was he who introduced us to each other. We both wanted him to be groom's man at the wedding, but he never replied. We lost touch eventually, but in this case he did reply. I don't wish to get any hopes up prematurely, but I'd be happy if he could at least show us some directions.

I dropped everything at the City University, although I will see if I can apply for leave while I'm in Manila. That's least priority, of course, but if I don't see to that, I will be cut from my stipend in less than a month. I have yet to see how I can make money in Manila. There were some promises from the people I called, but those 
words, though well-meaning, should not be taken as guarantees. In sum: I will try to send what I can.

Frankly, I have no idea how long our efforts will take. This means that I can't make time for Davao. In fact, if you see me at your door anytime soon, that would probably mean bad news. Yet I am confident. Take heart.

You are the best possible influence for Max and Curie during these times. Thank you for teaching them, for leading them in prayer.

Your son,

$\operatorname{Ian} K$.

\section{Dear Bridget,}

For months, I waited for your reply. I suspect you did not receive my last letter, so I shall repeat myself here. If you remember, your last letter was largely incoherent. You riddled it with abstractions and pieces of unnecessary songs. Read it a couple more times to understand you, but I succeeded with only a few islands of clarity. You thanked me for my letters, for the continuing flow of donations, and for inspiration. Inspiration for what? You have the Bible there. Any other oversea stimulant should be an excess.

I pay close attention to your letters, so mind what you write.

You said the Pastor's gone, and you've been collecting my letters to him. But gone where? I wish you didn't leave statements like that hanging without sufficient background story, Bridget. You had me worried: needlessly, I hope.

There were drops of blood on your letter. If that was not a nosebleed, maybe you should have explained that too. I have always admired your intelligence, your father prized it. Understand how deeply the form of your letter disturbed me.

Or, should I read the incoherence itself as your message? A tragedy? As series of? The word "Catholic" was in your letter among the words "livid," "option," and "paintbrush." Are you converting, is that it? 
I hope that's the sum of it, because we can talk to your father about that. Of course, I have yet to decode "gone" so I'm merely assuming that I could yet reach him. Bridget, I need the Pastor. My wife has been taken captive, presumably but highly likely by the military. So I will visit your house about a week after you get this letter. I hope the visit will benefit both of us, but if that's not possible, then we'll see what we can do about your particular situation.

With utmost concern,

Ian Kasimiro

Mari Tsuji received a rushed package via courier from Ian Kasimiro. There were four items in it, a red pen, a black permanent marker, a letter, and a separate sheet meant for Griff Johnson. His instructions were to read the letter, underline the things "you wish to be honored," and erase with the permanent marker "what you deem unimportant." It would be his last letter.

Mari blacked out the pleasantries, the "dear" and "sweet" and "love," the endearments, the strings of compliments, and everything that sounded to her like breathy bedroom whisperings. Only the instructions were underlined, whatever was written about his plans, the parts were he stressed that she was to dispose of his things and a passbook account that he had transferred to her name even before he left for Manila.

(1)

Look for the maroon envelope in the filing cabinet, the one bound with two strings. Inside, you'll find a passbook. You will need to check with the bank about that, but it is valid and entirely yours. A small sum, but it will cover a few months rent and advance should you decide to move out. Now, there should be three or more items there. A picture of my family which I took one particular red Sunday in Binondo-our Chinatown. That belongs to you as well. Store it or burn it. Although the possibility's much too slim to encourage hope, I might be able to bring my family to town. New York, that is. If I do succeed, they'll have instructions to speak with our landlady. I understand if you try to evade them. For your information, I shall likewise give Gina our picture. The one we took New Year's Eve. Our bright scarves. 
(2)

You may support the ministry too, but only if you wish it. Pastor Sheil's address and account number are in my address book...

(3)

I'm not keen on going back to New York, our vertical city. Nor would I encourage you to come to my country. People here are losing hope, the only thing able to sustain people like us. Still, a man who thinks he has lost all hope could actually stand to lose more. And more. Thinking of hope and even "losing" hope must be seen as activities. Every activity means change, one way or another. Things as petty as the Marcoses or as grand as the cosmos will either terminate or change. Stability is a most human fantasy. Entropy speaks against it.

Academically speaking, I was truly onto something. You said I never spoke to you about these things because of my native condescension, because you didn't have enough brain for me. In truth, I kept myself from telling you these things exactly because I knew you would understand.

Let me speak to you once and then never again of the paper in the maroon envelope. It's meant for you, but also for Griff Johnson, another scientist who played a part in the idea.

Here we go. We begin with zero.

Now, a state of zero entropy would mean that everything-quasars and sardines, you, and my children, and all dictators past, present, and future-has reached absolute zero temperature and has assumed the form of one entirely flawless crystal. That's to say, a dream of symmetry and invincible order.

Yet there is disorder, therefore (but this is oversimplifying!) change, and with change comes a grand array of possibilities (the greater the number of possibilities, the greater the entropy) and among those possibilities is the shift of galaxies, the rise of life from the darkest trenches to the peaks of mountains, cities, moon craters, fungi, the particular angle that describes my downfall, the exact manner with which you cross the street and plant your heel on the destined sidewalk with a sigh.

One other idea though is that there really was nothing-let's call it "before the universe" but it's perfectly clean, without star or feature or hair, can you imagine? There was neither time nor space; it was a lovely nothing of a nothing. The only thing about this nothing is that it is imperfect, and if you measure it in terms of order and disorder, it's almost equilibrium except for the thinnest slice, a small, almost infinitesimal kiss of chaos. That kiss gives us some angle, some room to play dice. 
So much dice, dice upon dice upon... well, plenty plenty that it's hardly fair when you're betting to see all billions of them turn up sixes, and most of the time they don't. Predictably. However, given enough opportunity-say, an infinite opportunity to throw all them dice-it's bound to happen: all sixes! A fluctuation in the vacuum.

Particle. Then particles. With enough proliferation of these little gravities, the capital B Bang. You know the story from there.

The $18^{\text {th }}$ century physicist Boltzmann - the only true and massively neglected prophet of entropy-speculated that the universe ought to have been in a state of complete thermodynamic equilibrium. Yet it's not, is it? Manifestly no, and that's why we have ice cream, and the ice cream parlour, and this earth of overflowing magma cooled by yet more seas, and upon this earth, the ice cream parlour which was built so you could wait for me to come and see you and likewise take a look at what an hour would do to a parfait on a summer afternoon.

Boltzmann thought the whole thing could have been the result of a temporary deviation from equilibrium. Hence, we derive our true cosmic nature-we are little disequilibria running around on two feet.

Neither accidents nor darling little serendipities, we just are because the possibility exists, a singularly negligible possibility that played up, played on, and would eventually play out.

(4)

I will not be able to publish this paper, but if it won't belong to Boltzmann, two possible claimants would arise: Griff Johnson and Tyrone Edwards.

Dr Johnson's claim is more legitimate. You have been repeatedly introduced to my collaborator, Edwards. He brings invaluable laboratory-type know-how to the table, a quick enough head for numbers, traits for which he would be generously awarded someday, but the deficiencies of his imagination considerably delayed the progress of our project.

Towards the end, he began to suspect what I was working on, its magnitude as a plausible and significant cosmological model, so I began hiding some pieces from him, and those pieces have been placed inside the maroon envelope waiting for the hand of Dr Johnson. I want to warn Dr Johnson about Edwards, he could make trouble, and so in the sheet I wrote for him, I indicated the nature of Edwards's contribution and some suggested evasive measures he could undertake in his own computations to see this paper come out quite free of Edwards's work. 
You might think me unrighteous, scheming as I now do against my own colleague. Trust me, Mari; it's more Johnson's property than his. Boltzmann's long gone, in any case.

(5)

\section{Dr Griff Johnson:}

I am Ian Kasimiro of the City University of New York, and I have followed Boltzmann's computations with a sustained enthusiasm that must at least rival yours. In Nature (volume 232 page 440, 1971), you said you were engaging several of Boltzmann's variations, particularly one that held "the possibility of the universe being born in fire, expanding, and then recollapsing into nothing." You put some recommendations for the further study of this variation, none of which I pursued.

I have in mind that the Big Bang was a vacuum fluctuation, likewise the rest of the universe. If the universe has zero net energy then the amount of time it is allowed to exist... can be very long indeed. The math I prepared for you will bear out that while it cannot be claimed that universes like ours do occur frequently, we find that the expected frequency is non-zero. You and I are precisely that non-zero, now, aren't we? But I-and now you, because I am unable to see this work to its completion-possess the math that may later prove to be the key to explaining us once and for all.

However, while I wish to give you this gift (it's all the same to me if you use my name or not), I'm afraid you may have to face the challenge of my erstwhile collaborator, Tyrone Edwards...

Finished with her markers, Mari Tsuji began playing with dice. The dice belonged to Ian Kasimiro who used to throw repeatedly on his drawing board, producing thuds and rolls that grated against her ears. She remembered the last time she heard him play the dice. It was after their argument, after the heated coupling that ensued. She woke up and heard him playing without let-up. She did not have the heart for another argument, so she faked sleep.

That was the night, yes, now she was sure.

The night when Ian Kasimiro was throwing dice for hours until it was dawn. It must have been the night he learned about the capture of his wife.

Mari Tsuji threw dice. She threw dice. And she threw dice until she did not notice or care to notice which dots turned up. Mari Tsuji threw and threw until she had perfectly replicated the sound of Ian Kasimiro casting dice. 
LUDWIG BOLTZMANN: Why did you omit my suicide?

IAN KASIMIRO: Would have sent the wrong signal, don't you think?

LB: The signal being disorder engendered the universe. So you still care for credibility. You thought that if you told Ms Tsuji that your beloved footnote was an old Viennese suicide, she'll see you as nothing more than just another schizoid disciple of death.

IK: We are all its disciples by virtue of none of us being its master.

LB: No mention even of the fact of my birth! Or my old joke of being born between-

IK: Mardi Gras and Ash Wednesday. God, not that again.

LB: Always got me far with the ladies.

IK: You believed your own hype, Professor. You kept saying that joke as an explanation for your mood swings, thereby excusing you from doing anything about them, therefore leading you to that last rope.

LB: Oh but the rope's been slung around my neck the day I was born.

IK: Now we brace our shoulders. We will fight.

LB: Stretch our spines. Throw ourselves to the lust of the hunt. Make a difference! Carve our names in blood, eat the Angel of History one feather at a time, dance the cha-cha-cha!

IK: If you don't believe that I'm looking for all my lost ones, then tell me what I'm trying to do here. If this is neither bravado nor ennui, what's your explanation?

LB: You want a change of view. Intimacy with the countryside. Noble savage kind of thing. Even back in my day it already sounded cliché. Well, you won't be at 
a loss for a job, little Ian. Every town craves for a math teacher. Right up there with rock stars and governors.

IK: Mari Tsuji will never understand.

LB: Oh, but did you ever desire her comprehension?

IK: I told her about you, Professor. Did you not read over my shoulder?

LB: I most certainly did, but with little relish. Your words never did justice to my science.

IK: Words were always too clumsy to do anybody any justice. The word "lifer" or "algae," or the words "Sunday" and "daughter," such curious things, forever available for the human need to rhyme once in a while.

LB: While farming or urinating in the countryside. Hunting and gathering.

IK: Maybe I have already introduced you to my wife.

LB: What's left then, Ian, shall we kiss the hands of your mother?

\section{DEAR DA,}

I wish Ian gave me more time and paper, but he says he needs the urgency and I could use the discipline. He says you could use the urgency too. Yet, how can I hope to write you? A handful of loose sheets and the space of an hour! Still, Da, I sense good intentions from him. He's meaning to look for you. He was thinking to ask for your help, but he understood that it was you who needed help. "It falls to the lost to look for the missing," said he.

The ministry's not doing so well. I've tried my best, please believe me. I've sent letters to ask for a new minister, but they're not yet sure. It's the country's situation, that's really what they're saying. They can't send another man. Why do I have the feeling they're waiting for a death certificate before they make a move? We're thinning out, Da. We're less than half the number when you left us. The choir yet sings, but we've sold the guitars. 
Where are you? Send word, please. This letter is torture, one minute I'm seeing myself talking to a well, the next I think I see you coming in from the pantry with the sound of your teaspoon dancing against your coffee cup. This letter was an activity of Ian's, do you remember? When it was his turn with the kids in Sunday school, he told them to write letters for God. Then he took the letters out on Christmas Eve to burn in a bonfire, told the kids to watch the smoke reach heaven. How loudly they cheered, Da, remember?

How terrible it is writing under these conditions, terrible, and on top of it, he won't quit looking over my shoulder, telling me to report to you, to forego feeling, you're one for news, take your feelings to Jesus, he told me. He still is mad at the last letter I sent him. I should learn to take a hold of myself, he says. Do it for the ministry. He seems to know exactly what you would tell me, exactly how you would tell me. Were you here. Around. But you are absent, painfully so, and I wish he wouldn't speak to me the way you would. The way that only you have the right to speak to me.

Good, he is saying, good, it's more "coherent" now. But I must forget myself, and think of you. Think toward you. See you holding this letter, opening it with your hands. Ian will take these to you. It will be the first thing you'll see if we succeed in retrieving you.

I have forgotten your hands. No, Da, you deserve honesty at least. It's true that I have tried so hard to forget them, and you, because there's no other way to assume your functions but to take you for gone, for away, in Ireland maybe, or New York. Why did you ever think of going here? Of staying too long? There's nothing left of Ireland for me to remember.

Ian said he wanted to you to help him through your network: ambassadors, pastors, anybody, but especially newsmen. Reporters and journalists preferably from Europe. He is looking for his wife. Like you, he says, missing. No, not at all like you (and I'm glad he's reading this!) because he had been informed-by his wife's friends - that she's in the hands of the government. But you, you just up and left one day. He's so sure you're desaparecido, and that you were never one to leave without telling. Is he right, that you have nowhere else to go? You're rooted, he said, and for someone like you to disappear, you had to be taken against your will. Where are you, Da?

Where are you... and why did you have to speak up against them like that? And in print too, as if your voice would not have damned us enough. Now here, your precious Ian Kasimiro wishes to take your path, asking for your list of newsmen. What help were these people? I myself called them up one by one. I asked extra 
from our people just so I could go from one door to another on a fool's errand. And now, Ian. Here. Why is Ian not merely another door?

He saw the slashes on my wrists. I know you would have disapproved, but heartily so, and with kisses, tears maybe. That was you. But he looked at them and said things like, Did you keep count? These slashes overlap. They weren't done all in one night, were they? Bridget, it takes strength to annul strength. If you desire to properly accomplish something like that, make sure it's on a full stomach, besides that method is ineffective-or were you aware, indeed wishing to be ineffective? For horizontal slashes to work, these must at least cut to the bone. What's the meaning of doing all this skin-deep? Glyphs are half-measures, Bridget. Either you are silent, or you express everything at once, which is also silence. The best way to do that (he guessed the instrument correctly, Da) with your father's razor is vertically. Slice right down the middle (he traced the skin of my wrist with this very pen and left his mark)-listen Bridget! Down the middle, between the bones, between ulna and radius as it were, let the razor seek the pulse between them. Drive those veins down to silence.

I feel embarrassed now when I look at your razor. But Da, I talked right back at him, I told him, You better bring the Pastor so he'll put you in your place!

I am in my place, he said. He gripped my wrists almost to the point of crushing them, showed me my scars, almost pushing them to my nose. These too are in place, he said, these have been in place before your father was taken, even before we met, Bridget, long before you came to this country. All the razor did was to reveal them to you.

Where are you, Da? I'm sorry I hurt myself. I'm asking for your forgiveness... I promise I won't do something like that anymore, and you can rely on me to be strong for you. I just want to know where you are, exactly. Why you're not coming back. I've run out of sheets,forgive that I will greet you in this haphazardly...shall be better after these words.You are my inspiration,Da.Your daughter misses you,Love,love,lov, love,loveloveBridget.

MAJOR WAJE: That's that then. There was nothing on the Pastor, and I doubt you'll get anything more on him. Let's focus on Gina, because our plan for her 
seems to me very sound. Risks will always be there, surely, but if I take care of my end-and you, of yours-we can hope for a pleasant resolution.

IAN KASIMIRO: I have been very lucky. Very lucky, but maybe it's more than that. Tia's room was luck. But my roommate, now that must have been divine providence.

MW: Gina's your jackpot, and you should not forget this. There's still much work to be done.

IK: Yes, do what you can to secure her release, and I'll get her to the States, even if I have to drug her.

MW: But you did forget her, didn't you? Once, or you wouldn't be here. Our business is settled, and now I can be frank: I should never have introduced her to you.

IK: Nor should I have gone to watch you that time.

MW: The judo try-outs, yes. There was no reason to invite you.

IK: No, it was the tournament-at the Ateneo gym-but yes, you invited me. It didn't seem to me one of those polite invitations; I did not feel obliged to turn it down. All the same, the choice was mine, my will was sound, and I shall forever regret accepting your invitation. Gina won in her division, do you recall?

MW: Iremember the event in general, though not her match. In such tournaments, a participant would not be able to watch anything more than snippets of the games other people were playing.

IK: In that regard-but maybe solely in that regard-a spectator has the advantage. I remember everything. The men's division won too, over-all, but you lost your match. Nobody could have foreseen the future in such a state. You were drunk for what remained of the semester. I had to cart you off to classes half the time. The air was so different back then.

MW: Those were the days. Crisp, and so different. Beer bottle after beer bottle. All those assignments you did for me... but why did PoliSci require so much math? A couple of freeloaders out to rummage in the world. You know how I loved both of you, Ian. And I still do. But some American reporter on your leash? What did you

take me for? 
IK: I had no idea which way the wind would blow. Can you blame me for employing some measure of insurance? One must not risk Gina any further, I mean, technically, she is your enemy. You can't refuse my apology.

MW: A solid man would have made sure his wife was home for the kids, Ian.

IK: You understood her better than I ever did, Major. Gina would be out for all children or none. Both of you were carved from principle, grade A material. Nothing so loose-hipped as myself could ever hope to erode either of you.

MW: Are you telling me that you can't be that man? Look, I won't go through all this trouble-and it is trouble, Ian, this will jeopardize my career, compromise the trust of my superiors in their man!- so understand that I won't exert my powers only to find her back in the mountains of Tiaong boiling camote with those apes. Or do you want her locked back in the zoo? You definitely cannot count on me for a second time, Ian. Not even with a platoon of reporters behind you.

IK: I understand, but I am a physicist. I read the play of forces with eyes somewhat akin to yours. I know her measure only as much as I know mine. Even if I sell my soul, I can't personally guarantee that I can weld someone like Gina into place.

MW: Then allow me to share the nature of $m y$ insurance, old friend. Like any human institution, the military breeds its share of outcasts. Can't be avoided. Most of these drop-outs are drafted by the politicos as the cream of their own baby armies. But the best of them can afford to work freelance. Hounds for hire. Three of them already have the picture of Mrs Kasimiro and her children. And children, take note.

IK: Perfect. Even in this last gesture, you reveal yourself a true friend. That's exactly the type of instrument I need, Major. You handed me a tool, yes, but to employ this tool, I have to tell her everything. Your intentions, I mean, with the pictures and the dogs. What you have in store for her should she decide to sneak back into the country without your clearance-

MW: And communicate to her comrades in any way.

IK: Copy that. But she will hate you.

MW: Fringe benefits. Learn to enjoy the things that can't be changed. She was the best of the batch. I don't recall ever telling you, Ian, how she inspired such awe in the boys. We'll get this done if you focus. Do you hear me? Concentrate.

IK: Diffusion was always the thing. 
MW: Forget the Pastor.

IK: I will never see you again, a fact that will make both of us happy. I shall not tell my children about you for fear that they would at some point mess up your desk with inherited carelessness. But if it happens, if you die before I do-death must also be in the fringes, of course, generals and majors being the pulp of international headlines - in that eventuality, do you think I shall be free to speak to them about you?

MW: Tell them to light a candle there in New York or Frisco. I was the brother you never had.

\section{Dear Mr Asumen:}

Kiss my children for me. Things are looking up for Gina; I can honestly say this to you now. But I need something from you. Find a way to contact the person/s who gave you the report on Gina. Tell them they can set the terms of the meeting, but I need to see them or any representative. I need this done as soon as possible. Give them this letter, and they'll probably understand what to do, what comes next. Make sure all messages are marked URGENT, please. This is all for now, we're about to move very fast. Tell them to keep up.

Your son,

$\operatorname{Ian} K$.

MARI TSUJI: Didn't you find seven months much too long?

GINA KASIMIRO: Seven months is seven months, it's enough for itself. It's almost a year since that trade has been sealed, Ms Tsuji. Ian went willingly. You could say he insisted on it.

MT: May I know if-Do you think it was necessary? 
GK: He's a positive liability to the movement practically speaking. Maybe the exchange drew a bit of the fire away from me and the children, something he thought to throw in to confuse the players. But really, the meat of it was to get me out of there, get me neutralized as soon as possible. The Major made sure we were alive. Ian's move was unnecessary. I'm surprised the movement took him in.

MT: Maybe the movement embraced him.

GK: The movement is overflowing with compassionate people. Always someone there relying on every single person to be of some use.

MT: Was he merely being dramatic then?

GK: Curious maybe. It's hard to tell, there had been years between us.

MT: You understand him.

GK: Walking hand in hand? That was long ago, before the ocean. Now look at the things it's leaving on my doormat.

MT: So Ian was being Ian.

GK: That has no value whatsoever, not if you really think about it, not as a meaningful statement. Between dead and alive, Ms Tsuji, I wouldn't place any bets on alive.

MT: May I ask what you will tell the children?

GK: Work hard, save money. Life's a bitch.

MT: About Ian, I mean?

GK: "Children," I'll tell them, "you had a father. Run along now, don't be home late."

MT: Will you show them the article?

GK: Nature. Volume 246. Page 396. 1973, hot from the academia. Cosmological Model Based on the Character of Vacuum Fluctuation dot dot dot, Edwards, and more dot dot dot. I'll have the kids sit on it right after they're done with the multiplication table. 
MT: I have been telling you, it was the idea of their father, his definitive scientific contribution. Please, don't let them suffer for my mistake.

GK: It's flat paper, dear, the very stuff of fish wrappers and origami. To whomsoever it belongs, it's durable tissue.

MT: It is their legacy, Mrs Kasimiro.

GK: You must not think that I neglected to thank him. I thanked Ian with all my heart.

MT: The children can hold it for a while, for a minute.

GK: I must pick them up in less than an hour. Take all of Dr Edwards with you, Ms Tsuji. Run along now, and leave no trace of your men here.

MT: I see this, and I see the door. What an odd place to find release.

GK: A day of days.

\section{Dear Mr Asumen:}

My father, our father. Raise my children under the best possible light.

IAN KASIMIRO: Or should I read the incoherence itself as your message? A tragedy? As series of? Inspiration for what?

LUDWIG BOLTZMANN: Why can't this thing fly any faster?

IK: But it's perfectly clean, without star or feature or hair, can you imagine?

LB: What's left then, Ian, shall we kiss the hands of your mother? 
IK: Would you rather have thorns?

LB: So tell me, what is the point?

IK: Are you prepared to admit that this distance between us could be cut in half?

LB: Have you so mean a stretch of imagination? Why did you shove me into this form?

IK: Can you blame me for employing some measure of insurance? Wasn't it a splendid idea for a gift?

LB: Why did you omit my suicide?

IK: You and I, how can we labor under the belief that you can actually touch me?

LB: Shall phenom all over the place, or shall have already phenommed, as if the universe had nothing better to do than play phenomena over and over until the vinyl gets degraded to a state of complete material incoherence?

IK: Gray came out a couple more times than any of the others, don't you see?

LB: Oh, but did you ever desire her comprehension?

IK: Can't they kiss your hands? Pray to you?

LB: Do you believe I made this aircraft possible?

IK: Do you remember where I came from?

LB: Why did you omit my suicide?

IK: You and I are precisely that non-zero, now, aren't we? What's the meaning of doing all this skin-deep?

LB: Do you honestly believe I made this magnificent aircraft possible? 